\title{
Academic Entrepreneurship: spin-offs in Sweden and the UK
}

\author{
Åsa Lindholm Dahlstrand \\ CIRCLE, Lund University \\ PO Box 117, SE-221 00 Lund \\ Sweden \\ Email: Asa.Lindholm_Dahlstrand@circle.lu.se
}

\author{
Helen Lawton Smith \\ Birkbeck, University of London \\ Malet Street, Bloomsbury \\ London WC1E 7HX, UK \\ Email: ubtm188@mail.bbk.ac.uk
}

\section{Nabhassorn Baines}

Birkbeck, University of London

Malet Street, Bloomsbury

London WC1E 7HX, UK

Email: nsrikasem@yahoo.com 


\begin{abstract}
Discussions of academic entrepreneurship often focus on efforts to commercialize inventions appropriated within the intellectual property (IP) system. However, studies in the U.S. have shown that a substantial amount of entrepreneurship happens outside of the formal IP system.

In the UK each university sets its own rules on ownership of IP. In a few European countries, like Sweden, an inventor ownership model is dominating. There is a lack of studies of European academic entrepreneurship outside of the formal IP system; and accordingly there have been few possibilities to analyze the effects of different institutional set ups.

To help fill this gap, this chapter analyses how different institutional settings affect academic entrepreneurship in Europe. By analyzing both patents and spinoffs (from Oxford University, UK and Chalmers University, Sweden) we will shed light on two processes for commercialization of university research. We empirically investigate university technology transfer at two different universities in two countries with a different inventor ownership regulation.
\end{abstract}

\title{
1. Introduction
}

It has been argued that Europe's research and industrial base has a comparatively limited capacity to convert scientific breakthroughs and technological achievements into commercial successes (e.g. the EU White Paper 1993). The perception of a strong European science base which is not translated into economic growth is often labelled the "European Paradox" (EU 1995). Over time, the focus has turned to the commercialization of publicly financed R\&D. Even though some reports (Arundel and Bordoy, 2008; Bergman, 2010) have pointed to positive trends in, for example, efforts to encourage the creation of university spinoffs, there is a strong belief that the EU under-performs in the commercialization of publicly funded science.

The discussion of academic entrepreneurship often concentrates on faculty efforts to commercialize inventions appropriated within the intellectual property (IP) system organized by university administrators, e.g. Technology Transfer Office (TTOs). There has also been an assumption that academic entrepreneurial activities are reflected through the disclosure of patents via TTOs. However, studies in 
the U.S. have shown that a substantial amount of academic entrepreneurship happens outside of the formal IP system (Fini, Lacetera and Shane, 2010; Markman et al, 2008). Possibly then, similar processes may exist also in Europe. This has clear implications for normative assumptions about the seamless linear processes of research to commercialization within the context of now worldwide societal objectives on capitalizing on knowledge (see Etkzowitz and Klofsten 2005).

The specifics of the political context are, however, crucial. For example, while in the UK, since the mid-1980s, each university has been able to set its own rules on ownership of IP, in a few other European countries, like Sweden and Italy, an inventor ownership model is dominating. There is a lack of studies of European academic entrepreneurship that happens outside of the formal IP system; and accordingly there have been few possibilities to analyze the effects of different institutional set ups.

To fill this gap, this chapter asks the question, how do different institutional settings affect the commercialization/exploitation of university research in Europe? In order to answer the question, we empirically investigate university technology transfer at two universities in two countries with a different inventor ownership regulation. The two cases are Oxford University in the UK and Chalmers University in Sweden. The Oxford case will be used to illustrate the university ownership model, while the Chalmers case represents the inventor ownership model. The two cases are selected because both universities have well-established commercialization systems. Both universities are also creating a high number of university spin-off companies. In the UK, only Cambridge University has created a higher number of spin-offs than Oxford. In Sweden, however, Chalmers University is only ranked eighth in university spin-off creation. The largest Swedish universities create even more university spin-offs. Thus, in relation to its size Chalmers is performing like an average Swedish university.

Our empirical data allow us to compare the formation and performance of academic spin-offs at the two universities. We investigate and analyze how Oxford academics involved in spin-off companies disclose or exploit patents inside or outside the formal university IP system. In the Chalmers case we have identified a high number of spin-offs, both by faculty leaving the university and by faculty keeping their university positions. Our comparisons will add further insights of the impact of different intellectual property ownership by highlighting these issues in the European context. By analyzing both patents and university spin-offs we are able to shed light on two processes through which the commercialization of university research occurs.

The chapter begins with explanations of the university spin-off phenomena. It focuses particularly on institutional conditions which influence the formation of university spin-offs. Next the methodology and results are presented. The results 
provide new insights and perspectives on technology transfer processes through university spin-off firms. In the last section, some conclusions are drawn and some limitations and recommendations for further research are discussed.

\section{University spin-offs and technology transfer}

The effort to create a knowledge-based economy has significantly emphasized the role of universities in commercializing new innovations including scientific and technological discoveries from the research laboratories (O'Shea et al., 2004). In addition, the importance of technology and knowledge transfer from university to industry including the necessity to build closer association between science/technology and its application and exploitation have driven the development of numerous entrepreneurial initiatives inside universities (Allen, 1995). The term, "the entrepreneurial university" (Etzkowitz 1983), was an early recognition of universities acting entrepreneurial, including a growing number of academic scientists in the US who were forming their own companies.

Numerous explanations of factors contributing to the formation of university spin-offs as well as other forms of commercialization through such as patents and licenses have followed. Four are highlighted. Firstly, legislative initiatives are widely regarded as contributing to an acceleration of the formation of spin-off ventures. For example in the UK, from 1985, universities were given autonomy to arrange their own rules and policies on IP ownership (Lawton Smith and Ho, 2006). Secondly, universities with cultures that embrace entrepreneurial activity not only have better rates of commercialization through patenting but also have high numbers of academic spin-offs than those which do not (O'Shea et al., 2004). Earlier Roberts (1991) proposed that a university's social norms and expectations are key factors in encouraging commercial activity. Thirdly, reputations including research prominence of universities are strongly linked to the rate of spin-off creation (Di Gregorio and Shane, 2003). Fourth, the regional knowledge infrastructure plays a vital role in supporting university spin-offs activity. Saxenian (1994), for example, illustrated that the formation of university spin-offs are more likely to happen in high-technology clusters because of easy access to local expertise, networks and knowledge. However, other evidence suggests that even when these are in place, they are not necessarily used by the spin-off firms (see for example Harrison and Leitch 2010).

The potential monetary, political and social pay-offs from such activities have motivated policy makers and university administrators to support these entrepreneurial activities. Of particular importance is the Bayh-Dole Act of 1980, which granted US universities ownership rights of academic intellectual property. In the 
UK, the government has provided financial and political incentive structures to support R\&D based entrepreneurial activity. By the year 2000, the number of spinoffs began to rise substantially in the UK. This was associated with an increase in the number of personnel working on technology transfer at UK's universities (Lawton Smith and Ho, 2006). In 2007/08, spin off companies from higher education institutions (HEIs) employed almost 4,500 people, had a turnover of more than $£ 73$ million and had acquired over $£ 52$ million in external investments (BIS 2009).

While many European nations have now abandoned the "Professor's privilege" (Geuna and Rossi, 2011), some US researchers, for example Kenney and Patton (2009), have criticized the university-ownership model, and suggest instead an "Alternative model" with inventor ownership. Indeed, comparing the inventor ownership model with the university ownership model, they conclude that this:

"...showed that the inventor ownership regime strikingly dominates the better funded, more highly rated, and much larger university ownership universities." (Kenney and Patton 2011, p. 1109)

The argument that inventor ownership has a positive effect on entrepreneurship is part of a growing literature that critically addresses institutional ownership. It is not necessarily the case that a Bayh-Dole-type institutional change will have a positive effect on technology transfer and economic growth. Kenney and Patton (2011) provided three examples where adopting a Bayh-Dole-type model has not been successful: Cambridge, UK (Breznitz, 2011), Japan (Carraz, 2008; Takahasi and Carraz, 2009) and Denmark (Valentin and Jensen, 2007). Of these, the University of Cambridge is the clearest case for showing that an inventor ownership model can be successful for transferring technology and encouraging entrepreneurship (Breznitz, 2011). Abandoning this model, to mimic the US Bayh-Dole model, in this case did not lead to increased technology transfer or entrepreneurship. Instead, there are indications that entrepreneurship, particularly in biotechnology declined.

In addition, most often, the academic entrepreneurial activities revealed by official statistics agencies are those that arguably take place inside the formal IP system such as industrial collaborations or consulting (Jensen and Thursby, 2001; Mansfield, 1995, 1998). The process of academic entrepreneurship is most often envisioned as a practice that begins with a disclosure of a new invention to a TTO, which then turns into a patented discovery that is either licensed out to companies or exploited to create a new company (Fini et al, 2010). This process has received attention from scholars, including studies of invention disclosure (Thursby and Thursby, 2005), patenting (Henderson et al., 1998; Mowery et al., 2002; Mowery and Ziedonis, 2002; Sampat et al., 2003), licensing (Jensen and Thursby, 2001; Jensen et al., 2003), and the exploitation of university-assigned IP to form new 
companies (Markman et al., 2004; Mustar et al., 2006; Nerkar and Shane, 2003, Shane 2004). The multi-dimensional characteristics of university-industry linkages (Agrawal 2001; Bonaccorsi and Piccaluga 1994), which can also be considered as entrepreneurial activity, include a range of avenues (Cohen et al. 2002; D'Este and Patel 2007; Faulkner 1994) or 'mechanisms' (Meyer-Krahmer and Schmoch 1998) in which knowledge and resources are exchanged and co-created between universities and industry without any occurrence of IP disclosure through formal systems.

There has been a distinct move away from the Professor's privilege in Europe towards various systems of institutional ownership in the belief that the commercialization of research results will be facilitated (EU, 2007, 2008, 2009; Geuna and Rossi, 2011). Sweden is now one of few European countries who have not abandoned the Professor's Privilege. This is so despite several national government investigations and repeated arguments by e.g. the OECD that Sweden should change this institutional setting. In a recent paper, Jacobsson, Lindholm Dahlstrand and Elg (2013) discussed this "dominant belief" and the commercialization of academic research in Sweden. They found strong indications that Sweden was performing quite well, both in terms of the number of university spin-offs created and the amounts of patenting originating in Swedish Universities. They argue that in the Swedish case, where about 80 per cent of the academic patents were found to be assigned to industry, abandoning the Professor's privilege for a University ownership model could well have negative effects since it would risk disrupting the strong knowledge sharing networks. As Geuna and Rossi (2011, p. 1075) argue:

"In countries where university enforcement of IPR has traditionally been weak...because of the professor's privilege....academic inventors have...patented their inventions individually or assigned IPR ownership to collaborating firms. In these contexts, regulations ...enforcing university ownership may increase university-owned patents at the expense of university-invented patents. Care must be taken...not to disrupt pre-existing functioning knowledge transfer relationships between academic inventors and firms."

Jacobsson et al. (2013) concluded that there is strong evidence that a) substantial academic patenting activity takes place in Sweden, although 'invisible' without detailed scrutiny of patent data bases, and b) the IPR rests within the business community to a greater extent than in other countries - and that the transfer mechanism obviously works. They base this conclusion on a few earlier studies of academic patenting, e.g. Lissoni et al. (2009) which set out to specify this magnitude in several countries, including Sweden. They capture patents held by individual researchers as well as by firms collaborating with an academic researcher who is the inventor, but not the owner. The share of academic patents, defined in that way, of total patents was found to be at the same level in Sweden as in the U.S. (6 
per cent) and higher than that of France and Italy ${ }^{1}$. The significance of this relatively high figure is magnified by the extensive patenting activity for Sweden as a whole. Hence, Swedish academics account for a high share of an internationally very high number of patent applications.

As mentioned, most of these Swedish patents are, however, not owned by the academics but by firms collaborating with Universities. Geuna and Rossi (2011, Table 5) point to a very high Swedish share of business ownership (81\%), higher than other European countries. Moreover, these European shares are much higher than that of the USA. In the Swedish case, the top companies owning academic patents include large multinational companies which interact to a great extent with universities and obviously very often come out of that collaboration with the IPR.

In addition to patenting and university-industry networking, Jacobsson et al. (2013) also analyzed different categories of university spin-offs. In earlier studies there is a great variety in definitions and measurement of university spin-offs. One main issue has to do with whether it is research/technology that is spun-off or if it is the individual researcher who leaves his/her employment to set up a new firm. In their definition of university spin-offs, Jacobsson et al (2013) included both direct university spin-offs and two categories of firms that involve spinning off knowledge from University research, see Figure 1. Direct university-spin-offs are established by university researchers themselves, both by researchers leaving the university and those staying and creating a side-line firm.

Fig. 1 Categories of spin-offs founded on Swedish university research. (Source Jacobsson, Lindholm Dahlstrand and Elg 2013)

\footnotetext{
${ }^{1}$ The US share of 6 per cent is calculated by Lissoni et al., (2009), based on Thursby et al., (2009). For Sweden, Ejermo (2011) arrives at a figure of 4-5 per cent, but using the same method of Lissoni et al. (2009) he adjusts the figure to 6 per cent (Ejermo, 2012).
} 


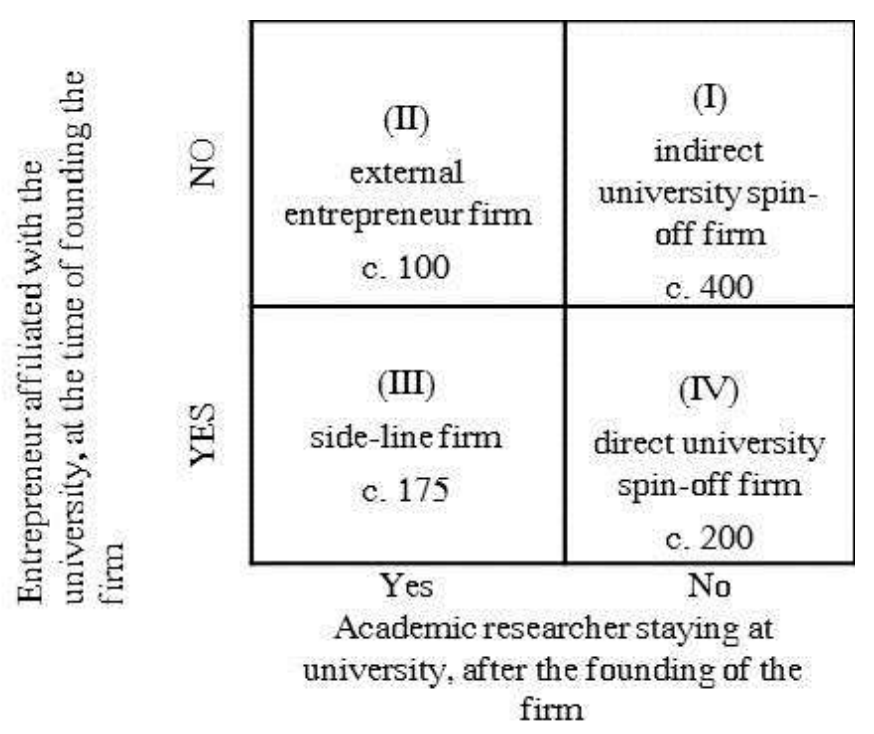

Among the indirect spin-offs, Jacobsson et al (2013) include firms established by previously employed university researchers (alumni) but not until the founder has worked an additional time in industry. In addition are firms founded by an "external entrepreneur" who is not the university researcher. In these firms, the university researcher stays with the university and keeps his/her university employment. Taken jointly, they estimated that about 875 new firms were started every year based on university research in Sweden.

Unfortunately, Jacobsson et al. found no available international data that were directly comparable with the Swedish. One reason for this is that in countries with a university ownership model, it is normally the IP and the disclosures that are measured, for example by university TTOs and associations like AUTM in the US. This means that in available spin-off data, information is not usually given about whether the university researchers have kept their university employment or not. Even so, they presented a rough comparison with UK and US spin-off data. The UK data were drawn from HE-BCI survey ${ }^{2}$ and US data by AUTM ${ }^{3}$. Their finding was that the figures for both UK and US were of the same magnitude as

\footnotetext{
${ }^{2}$ Funding of British HEIs (Higher Education Institutes) partly depends on spin-off creation, and, thus, the data reporting is not likely to be an underestimation. See http://www.hefce.ac.uk/econsoc/buscom/hebci/ This data is collected annually from British HEIs since 2003.

${ }^{3}$ The AUTM data only report spin-offs based on disclosures registered at participating universities. It should be noted that the AUTM studies only include data from less than 200 US Universities. These universities are, however, the most research intensive ones. AUTM data for 2004 to 2010 is available at http://www.autm.net/home.htm
} 
the direct university spin-offs in Sweden (only quadrant IV in Figure 1). The AUTM reports some 400 to 650 university spin-offs each year, while the British HE-BCI survey reports between 150 and almost 300, i.e. within the range of the figures for Sweden.

Moreover, since the US and the UK data only report spin-offs based on disclosures registered at participating universities, that is, within the IP system, this would suggest that the figures seriously underestimate the total spin-off frequency (Åstebro et al, 2012). This problem was discussed by Fini et al. (2010) who found that only 35 percent of new firms started by university researchers in the US were based on patented inventions within the IP system. Correcting for this would mean that the US figure should be increased to about 1600 spin-offs per year.

To inform and provide faculties, universities and policy makers with more accurate picture on academic entrepreneurial activities and parameter than the only mechanism of patents disclosure via formal IP channel is one important aim with this chapter. Here we ask how different institutional settings affect academic entrepreneurship and the commercialization of university research in Europe.

\section{Method}

This chapter uses two case studies - Oxford University in the UK and Chalmers University in Sweden - to analyze and compare technology transfer and university entrepreneurship in two different institutional contexts.

\section{The Oxford Case}

The University of Oxford is one of the world's top universities. Oxford offers more than 320 different graduate degree programmes and has over 9,800 graduate students from more than 140 countries and territories, over 5,500 graduate research students and nearly 12,000 undergraduates. Oxford's research activity involves more than 70 departments with over 10000 employees, including 1,600 academic staff and 3,000 research staff. In 2011-12, total University income was $£ 1,016.1$ million, out of which about half was research. External research grants and contracts is the University’s largest source of income. In 2011-12, 40\% (£409 million) of income came from external research sponsors. 
In a world university rankings published by Times Higher Education in 2012/13, Oxford University is ranked 2nd. Its place in this ranking is owing to unique qualities, i.e., high concentration of "world-class scientists", the world's second best university in medical and the fifth best university in biological science disciplines (QS World University Ranking, 2012), as well as a number of interdisciplinary research centers, which some have links with international academic and industrial partners (Lawton Smith and Ho, 2006).

Oxford University has an elite and very well-established commercialization system; it also creates three times as many spin-offs as UK universities on average. Only Cambridge University has created more spin-offs than Oxford has. The key mechanism for creating university spin-offs is through Isis Innovation, the university's technology transfer company, established in 1988. Commercialization activities, however, only started to take off and expand in 1997 following the appointment of a successful entrepreneur and business angel as CEO (Lawton Smith and Ho, 2006). Since then, Isis Innovation has been in charge of generating spinoff firms based on academic research produced within and owned by the University. So far it has supported the formation of more than 75 companies. It has created a new spin-off company every two months on average (Isis Innovation, 2013). Since 2000, external investment of over $£ 266$ million has been raised by spin-off companies, and 5 Oxford spin-off firms have been listed on London's AIM market. Besides, in 2012, Isis Innovation filed 100 patent applications on behalf of the University; it also manages over 470 patent application families as well as $700 \mathrm{li}$ cense agreements (Isis Innovation, 2013). It is claimed that licensees and commercial partners are solicited from both national and international technology and business sectors. In the Oxford case we use a sample of university spin-offs which is drawn from the existing database of 75 companies spun out from the University of Oxford and published on the Isis Innovation website.

In the data collection process, first we use the ICC Directory of UK Companies provided by Lexis Nexis and Companies House (lexisnexis.com/uk/nexis/search and companieshouse.gov.uk) which contained detailed profiles of the companies including the company's registered address, date of incorporation, board of directors, any subsidiaries which the company may own, key facts about the companies, and financial data. In this study, we identified and listed names of directors of all 75 Oxford spin-off companies. Second, we cross-checked all director names with the University of Oxford's contact search database to find out who is an academic and in which departments or colleges he/she is currently working. However, the database does not provide the period(s) of employment with the University of Oxford. Third, to investigate the patents' profile of the Oxford university academics, patent searches were done via the Espacenet of the European Patent Office.ESP@CENET on the European Patent Office website includes records of the patents filed by companies which can be accessed and searched by a range of criteria such as applicant name, inventor name, and so on. We conducted the search 
by inputting the name of an academic as an "inventor" and put in different applicants beginning with (i) "name of academic", (ii) "Isis Innovation", and (iii) "company name". This patents search process is repeated for all academics in the database.

We recorded the following details: i) number of patents, ii) publication date (the date when the patent is filed) iii) applicants or assignees, iv) European classification number. In addition, we noted down whether the patents were assigned to Isis Innovation or the University of Oxford, or, otherwise, were filed under other names. This is used to determine if the patents filed stay within the University IP system or have bypass potential. We also report on the size of university spin-offs (employees and turnover) within the university system and with a potential bypass.

\section{The Chalmers case}

Chalmers University of Technology, in Gothenburg, Sweden, is one of the oldest and largest institutes of technology in Sweden. It offers Master of Science degrees, Bachelor degrees and doctoral degrees. Research is carried out in the main engineering sciences as well as in technology-related mathematical and natural sciences. Some 2300 employees work at Chalmers' 17 departments. Of these some 1600 are teachers and researchers. The turnover is around $£ 0.25$ billion a year (2011); two-thirds of this sum relates to research. Thus, Chalmers amount of research is around a third of Oxford's (i.e. 30\% of research income, 34\% of research staff).

Since 2000 Chalmers has a vice-president who is responsible for external relations. A strategic decision is that the processes of knowledge transfer and commercialization should be fully integrated with Chalmers research and education activities. Approximately 60 full-time equivalents work with knowledge transfer and commercialization at Chalmers. In addition several hundreds of persons from business work pro-bone as advisors, board members, industrial faculty, etc., thereby supporting Chalmers' knowledge transfers and commercialization activities. On behalf of the Ministry of Education, Chalmers established the so called Innovation Office West, in 2011. This Office has a role as an innovation advisor to Chalmers as well as seven other regional HEIs. In 2011, the Innovation Office established a support role for research-verification, where 37 validation projects were started which include analyzing the commercial potential of research results.

Venture creation is another important process for Chalmers' commercialization of new knowledge. Through the combination of the entrepreneurial school, incu- 
bators and seed investments, with an emphasis on active ownership, Chalmers has achieved great success with respect to this value creation process. In 2010, the portfolio companies in the Chalmers venture creation process had a turnover of over $£ 43$ million.

By the creation of strong links between education and exploitation of knowledge, Chalmers School of Entrepreneurship has developed a unique venture creation model that has been recognized both nationally and internationally. The idea with this action-based school is to educate people, not about entrepreneurship, but through entrepreneurship. Through this Chalmers contributes with entrepreneurial graduates to the regional / national innovation system. In 2011, Chalmersinvest, Encubator Holding (linked to the School of Entrepreneurship) and Chalmers Innovation Seed Fund invested around $£ 2$ million in new ventures.

In the Chalmers case the university has provided a list of the names and home addresses of every faculty employee as of spring 2012. Out of the identified 1191 researchers we excluded visiting professors and others with a temporary employment, ending up with a list of 921 professors, docents, lecturers, and post docs. We used the database Retriever to identify all kinds of private company activities of these researchers. We found 276 persons with some kind of company engagement. After excluding for example sole proprietorship and engagements as director of the board in other kinds of organizations, we finally identified 207 incorporated firms created by Chalmers faculty. We used the Espacenet to do a patent search for all the identified university spin-offs as well as for the individual researcher who had created the spin-off.

To complement the data on spin-offs in the Chalmers case we also used the MONA database of Statistics Sweden to find university spin-offs created by faculty who has left the employment at the university. This data consist of Swedish matched employer-employee panel data where we can find information on all new university spin-offs set up by researchers leaving the university between 1997 and 2009. In doing so we found 62 firms created by former Chalmers employees. Unfortunately the use of this database didn't allow us to identify the firms or the patents held.

In addition, the use of the MONA database allowed us to compare Chalmers with other Swedish universities. Despite a high number of university spin-offs, we found that Chalmers was only ranked eighth of all Swedish universities in spin-off creation. Larger universities, like Lund University, created many more university spin-offs each year. Also, in Sweden, Chalmers is ranked tenth in size (number of full time researchers). Thus, we found that, in relation to size, the frequency of Chalmers' university spin-offs is similar to an average Swedish university. 


\section{Findings}

In this section we are presenting facts about the spin-off firms from each of the two universities. This includes data on the firm's patenting and performance, and on the university affiliation of the academic directors.

\section{The university spin-off firms}

First, for the 75 spin-offs from Oxford University, we found that one company is a non-trading company and 9 companies are dissolved or in liquidation. Also, one company is registered in Belgium, hence there is no information registered in the UK Companies House. More than 50 companies have operated between 1-10 years, 18 companies have been in operation between 11-15 years, while only 5 companies have been in business longer than 16 years (Figure 2).

Fig. 2: Number of Years in Operations - Oxford spin-offs.

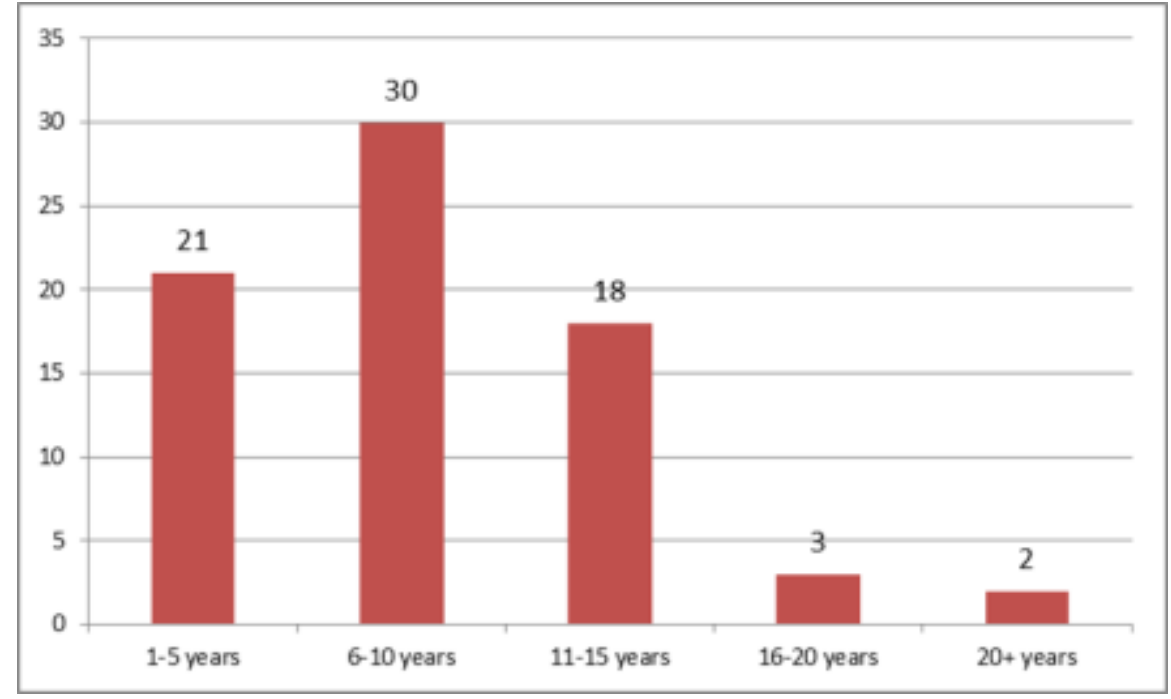

For Chalmers we identified a considerably higher number of university spinoffs, a total of 207 incorporated firms created by researchers still employed at the university in spring 2012. Out of these eight are no longer active, and we lack data of founding year Thus, out of the 921 academic researchers employed at Chalmers in 2012, there were 129 researchers (14\%) who had created an incorporated firm. This means that researchers active in company formation on average started 1.67 
incorporated firms. The oldest four firms were established in the 1960s, and the average age of all 199 firms (where we know the founding year) was 11,26 years.

Fig. 3 Number of years in operation: Chalmers spin-offs.

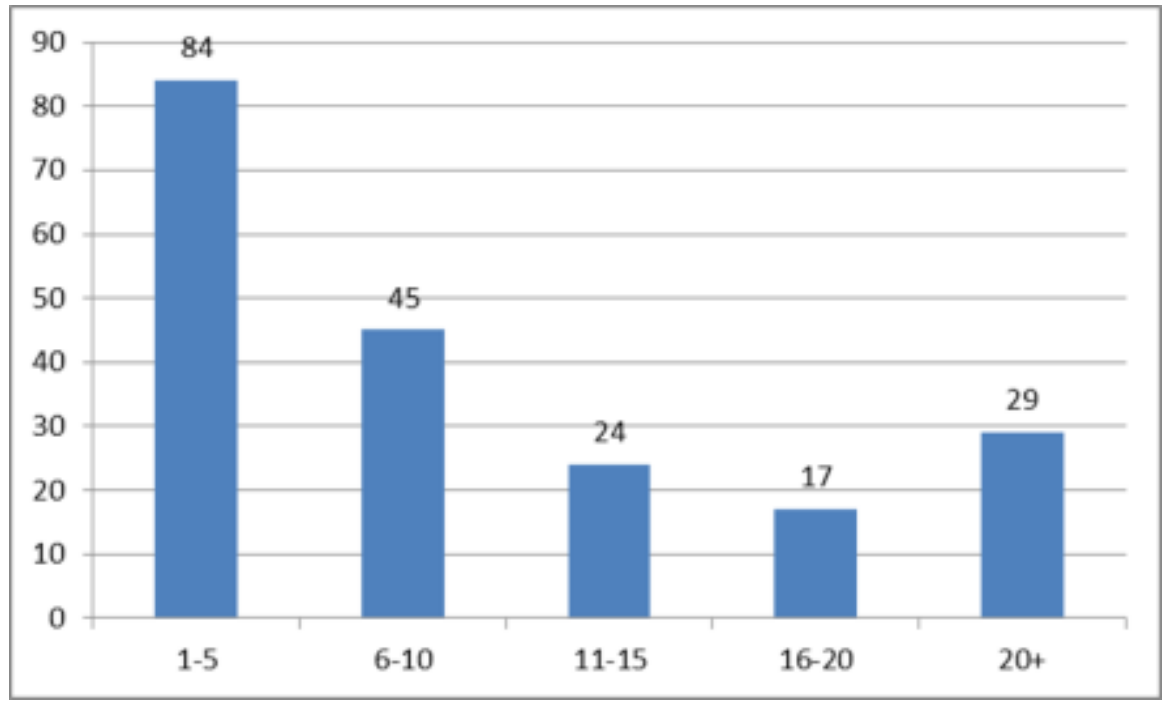

In addition to analyze spin-offs set up by researchers employed at Chalmers University we also used the Swedish MONA database of Statistics Sweden to find out the total number of spin-offs created from Chalmers University. The MONA database consist of Swedish matched employer-employee panel data where we can find information on all new university spin-offs set up by researchers leaving the university. The database provides information on spin-offs created between 1997 and 2009. In this period, there were a total of 164 new firms created by Chalmers researchers (excluding post-docs, $\mathrm{PhDs}$ and visiting researchers). Out of these we found 62 spin-offs where the researcher, in the first year after start-up, had gained a higher income from his/her own firm than from a university employment. These 62 firms are then - most likely - direct university spin-offs where the researcher has left his/her university employment. Thus, these firms are in general not included among the 207 firms identified among the researchers still employed at Chalmers. We can therefore conclude that Chalmers's academic researchers generate far more spin-offs than is the case in Oxford. Moreover, that this is not a recent phenomenon.

Figures 4 and 5 show the sectors where the university spin-offs are established. Figure 4 shows the diversity of the Oxford companies; the largest group within the sampling firms is in pharmaceutical and biotechnological sector, followed by engineering, software and chemistry sector respectively. The Chalmers spin-offs, 
Figure 5, are dominated by engineering firms (out of which "research and consulting" is the largest group). Medtech and biotechnology spin-offs are not very frequent, something which is of course related to the fact that Chalmers is a technical university without any medical research. We do not find many "research and consulting" spin-offs in the Oxford case. Probably such firms exist, but are not recorded and owned by Isis Innovation. However, if we exclude the "research and consulting" spin-offs from Chalmers, we still find 105 university spin-offs from Chalmers. With respect to Oxford University's research being three times the size of Chalmers, this is a very high figure.

Fig. 4: Sector- Oxford spin-offs .

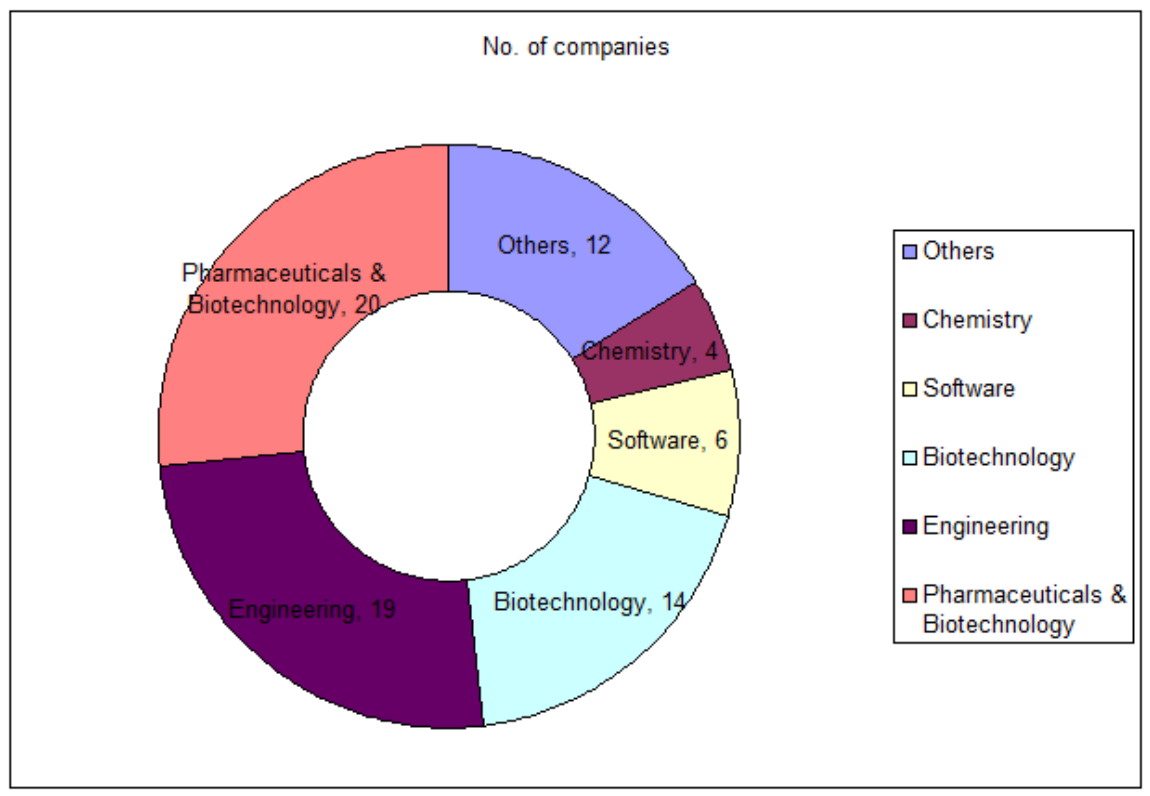

Fig. 5: Sector- Chalmers spin-offs. 


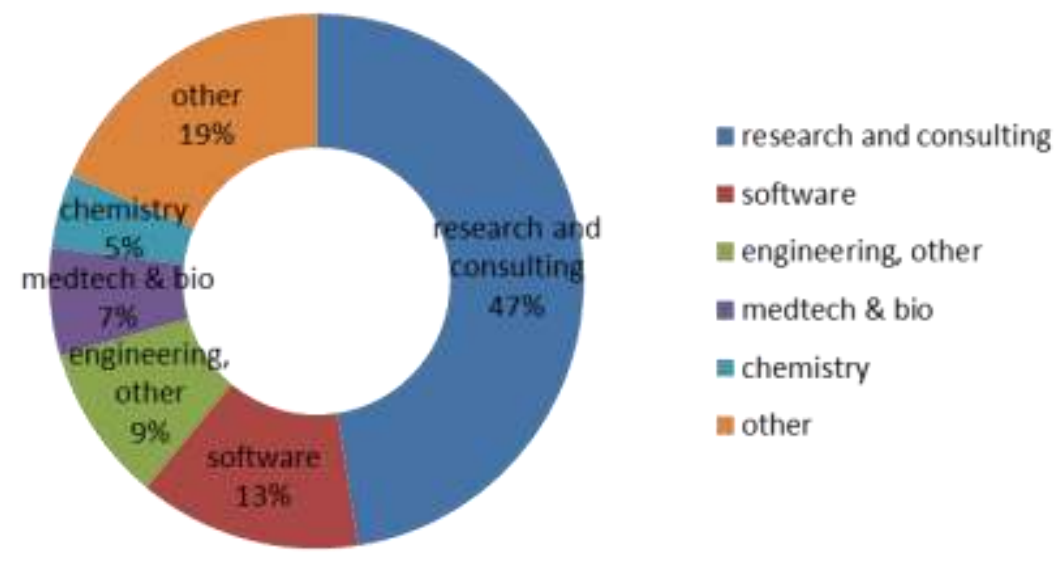

We used a binary logistic regression to analyze the differences between Oxford and Chalmers spin-off formation, Table 2. First, the chi-square tests of the logistic regression model were significant for both groups of spin-offs and indicates that a significant relationship exists between the entire set of independent variables and the dependent variable (i.e. being an Oxford spin-off).

Table 2: Probability of Oxford/Chalmers spin-off creation (binary logistic regression).

\begin{tabular}{|c|c|c|c|c|c|}
\hline & B & S.E. & Wald & Sig. & $\overline{\operatorname{Exp}(\mathrm{B})}$ \\
\hline age &,- 029 &, 024 & 1,430 &, 232 &, 972 \\
\hline company patents &, 325 & ,097 & 11,149 &, 001 & 1,384 \\
\hline biopharma & 1,713 & ,453 & 14,329 &, 000 & 5,546 \\
\hline engineering & 1,084 & .452 & 5,752 &, 016 & 2,956 \\
\hline consultancy & $-2,672$ &, 800 & 11,162 & ,001 &, 069 \\
\hline Constant & $-1,333$ &, 349 & 14,544 &, 000 &, 264 \\
\hline$-2 \log$ - ikelithood & \multicolumn{5}{|c|}{192,34} \\
\hline Cor \& Siel $R 2$ & \multicolumn{5}{|c|}{371} \\
\hline Napelhe be R? & \multirow{2}{*}{\multicolumn{5}{|c|}{$\begin{array}{c}538 \\
126,06(5) \cdots\end{array}$}} \\
\hline $\operatorname{cks} 2(x)$ & & & & & \\
\hline Sicorrest predictions & \multicolumn{5}{|c|}{228} \\
\hline
\end{tabular}


Table 2 confirms that there are significant differences in spin-off formation at the two universities. The Oxford spin-offs are characterized by having more patents $(p<0.001)$, and being established in the biopharma $(p<0.000)$ or engineering sectors $((p<0.02)$. Chalmers spin-offs are more often found in the research and consultancy sector $(\mathrm{p}<0.001)$.

\section{Academic Characteristics and Patents Ownership}

There are 122 academics from the University of Oxford involved in spin-off companies: 114 are male and 8 female. The average age for male academics is 56 years old, while 51 years old for female academics. Despite being a technical university with relatively few female researchers, the share of women directors is higher in the Chalmers case. While only $6.6 \%$ of the academic directors in the Oxford spin-offs were women, the corresponding figure in the Chalmers spin-offs is $15 \%$. Also in the Chalmers spin-offs the male founders are slightly older than the females; 53.7 years vs 52.2 years. In the Chalmers spin-offs the average age of the founder is 53.42 years.

There are very large differences between the two cases when we compare the frequency of patenting in the spin-offs (Figures 6 and 8). Figure 6 shows that more than half of the academic directors from Oxford own 1-10 patents, while as many as 27 of them possess more than 11 patents. In addition, we discovered that $47 \%$ of the Oxford spin-offs' patents were filed within the University IP system, whereas $53 \%$ of patents have filed outside the University IP system.

Fig. 6: Number of Patents Owned by Academics in Oxford spin-offs. 


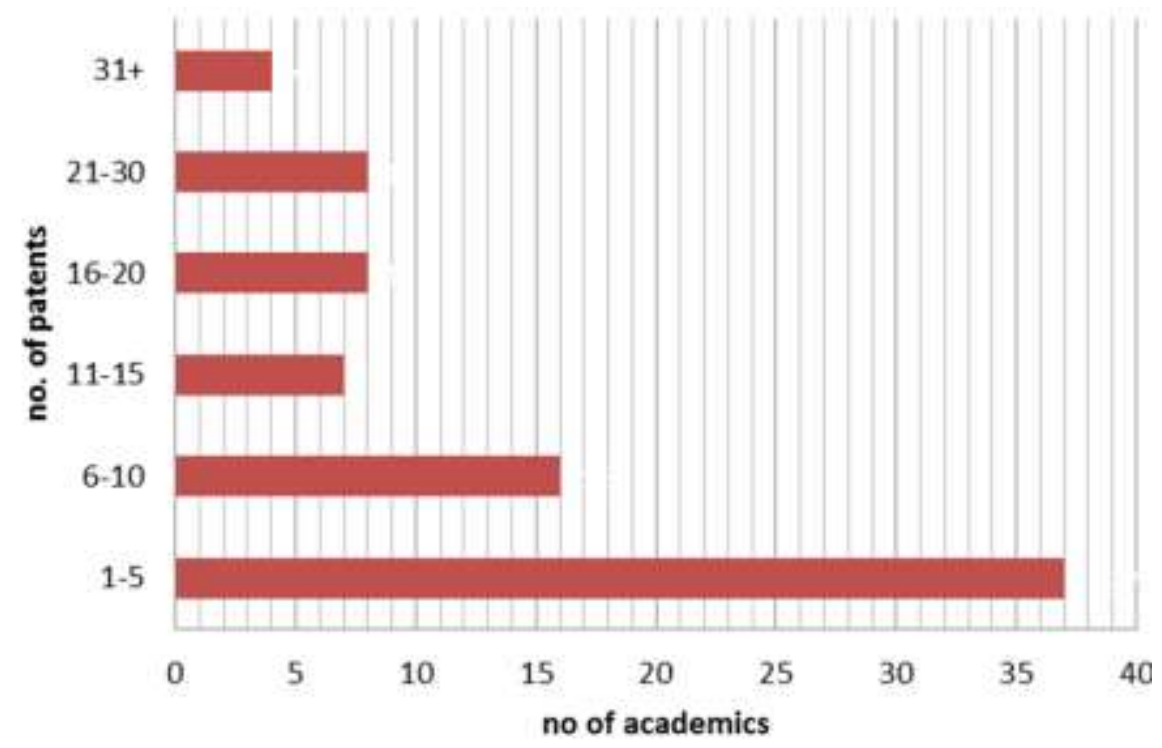

Most of the academics in the Chalmers spin-offs do not own any patents (Figure 7). Together all the 199 spin-offs own 94 patents. Only 33 of the spin-offs have any patents at all. No firm holds ten patents or more. Moreover, it is not always the academic him/herself who is registered as the inventor. In fact, only 17 of the 129 academic directors have invented patents owned by their own firms. Together these individuals have 39 patents.

Fig. 7: Number of Patents in Chalmers spin-offs. 


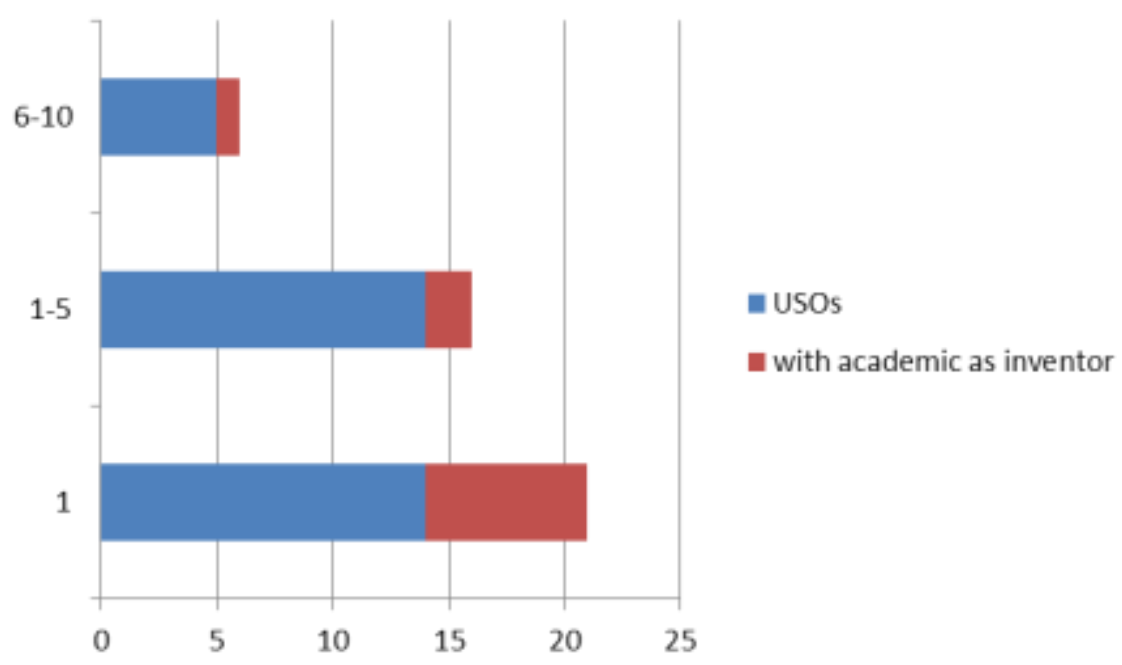

Since the Swedish law gives the IP rights to the individual academic researcher, there cannot be any bypassing within the Swedish system. But, as was found by Lissoni et al (2009) and Geuna and Rossi (2011), in the Swedish case academic patents are most often applied by existing firms. Elaborating a bit with the KEINS data $^{4}$ for Chalmers we find that between 1980 and 2001 the database includes 102 Chalmers-invented patents and 39 academic inventors. However, the assignees of the Chalmers patents are mainly (68.6\%) large existing firms, over $50 \%$ of the patents are assigned to five large companies (Ericsson $22.6 \%$, Kvaerner $8.8 \%$, Pharmacia\&UpJohn 7.8\%, EKA 5.9\%, Berol 5.9\%). Only $21.6 \%$ are assigned to university spin-offs (15 start-up firms). Using the Espacenet to do a patent search for these 15 university spin-offs we found that they own 104 patents, (out of which 22 included in KEINS data). 36 of these were granted between 1980 and 2001 and 68 between 2001 and 2011. This means that the average spin-off firm held 6.93 patents. Thus, in the Chalmers case, where the IP rests with the academic inventor, this leads to a high share of patents being assigned to large existing firms. Few of the university-spin-offs are patent-based, but there is a fraction of spin-offs that are assigned a relatively high number of patents.

\footnotetext{
${ }^{4}$ The KEINS database on academic inventors contains detailed information on university professors from France, Italy, and Sweden, who appear as designated inventors on one or more patent application registered at the European Patent Office (EPO), 1978-2004. It was produced for the EU-sponsored project on Knowledge-based Entrepreneurship: Innovation, Networks and Systems, and is made available to all interested researchers through the CESPRI website. http://www.cespri.unibocconi.it
} 


\section{Size of the University spin-offs}

The size distribution of spin-off companies in the Oxford sample by employees and turnover is shown in Table 3. Taken together the 75 Oxford spin-offs employ almost 4000 persons, and have a turnover of 430 million pounds. Thus, in the $\mathrm{Ox}-$ ford case the 4600 academic and research staff has generated an additional 4000 new jobs in the spin-offs (a ratio of $3959 / 4600=0.86$ ).

The majority of firms are however small (nearly three quarters). The exception being that there was one large company that did not go through Isis Innovation (1834 employees and a turnover of $£ 337$ million).

Table 3 Number of employees and turnover in Oxford spin-offs, inside and outside the Isis Innovation system.

\begin{tabular}{|c|c|c|c|c|c|}
\hline $\begin{array}{l}\text { No. of } \\
\text { employees of } \\
\text { companies }\end{array}$ & $\begin{array}{l}\text { outside isis } \\
\text { system } \\
(n=41)\end{array}$ & $\begin{array}{c}\text { within Isis } \\
\text { system ( } n=34 \text { ) }\end{array}$ & $\begin{array}{l}\text { Turnover of } \\
\text { companies }\end{array}$ & $\begin{array}{c}\text { outside Isis } \\
\text { system ( } € \text {, } \\
n=41)\end{array}$ & $\begin{array}{c}\text { within isls } \\
\text { system (f, } \\
n=34) \text { ) }\end{array}$ \\
\hline$N / A$ & 6 & 0 & $N / A$ & 9 & 3 \\
\hline \multirow[t]{3}{*}{0 (dissolved) } & 4 & 3 & -0 & 3 & 4 \\
\hline & & & $125 \mathrm{k}$ & 6 & 4 \\
\hline & & & $25 k-50 k$ & 0 & 1 \\
\hline \multirow[t]{2}{*}{1.10 (micro) } & 11 & 13 & $50 k-100 k$ & 3 & 1 \\
\hline & & & $100 \mathrm{k}-250 \mathrm{k}$ & 1 & 5 \\
\hline \multirow[t]{2}{*}{$11-50$ (smail) } & 9 & 9 & $250 \mathrm{k}-500 \mathrm{k}$ & 4 & 3 \\
\hline & & & $500 \mathrm{k}-1 \mathrm{~m}$ & 3 & 4 \\
\hline $50-250$ (medium) & 10 & 9 & $1 m-10 m$ & 10 & 8 \\
\hline $250+$ (large) & $1^{2}$ & 0 & $10 \mathrm{~m} *$ & $2^{b}$ & 1 \\
\hline $\begin{array}{l}\text { Total } \\
\text { employment }\end{array}$ & 3079 & 880 & $\begin{array}{l}\text { Total turnover } \\
\text { (kE) }\end{array}$ & 401865 & 28758 \\
\hline $\begin{array}{l}\text { Mean } \\
\text { employment }\end{array}$ & 75.1 & 26.0 & $\begin{array}{l}\text { Mean turnover } \\
\text { (kf) }\end{array}$ & 9802 & 846 \\
\hline
\end{tabular}

a) One Oxford spin-off formed outside Isis system is a large outlier (1834 employees and a turnover of $337300 \mathrm{kf})$. Excluding this firm reduces the total employment into 1614 employees (average 31.1 employees) and the turnover into $64565 \mathrm{k} £$ (average $1614 \mathrm{kf}$ )

The pattern for turnover is rather varied. On the whole, more of those which have bypass potential have a higher turnover, which might suggest an association between the ownership regime and performance. 
Only very few of the Chalmers spin-offs are patent-based firms. To see if this affects the performance of the Chalmers spin-offs we choose to separate spin-offs with and without patents. Table 4 presents the number of employees and the turnover (in pounds) of the Chalmers spin-offs.

Table 4 Number of employees and turnover in Chalmers spin-offs (with and without patents).

\begin{tabular}{|c|c|c|c|c|c|}
\hline $\begin{array}{l}\text { No. of } \\
\text { employees of } \\
\text { companies }\end{array}$ & $\begin{array}{l}\text { with patents } \\
\qquad(n=33)\end{array}$ & $\begin{array}{l}\text { without } \\
\text { patents } \\
\text { (n=166) }\end{array}$ & $\begin{array}{l}\text { Turnover of } \\
\text { companies }\end{array}$ & $\begin{array}{c}\text { with } \\
\text { patents } \\
(f, n=33)\end{array}$ & $\begin{array}{c}\text { without } \\
\text { patents (f, } \\
n=166 \text { ) }\end{array}$ \\
\hline$N / A$ & 3 & 26 & $\mathrm{~N} / \mathrm{A}$ & 3 & 26 \\
\hline \multirow[t]{3}{*}{0} & 7 & 59 & -0 & 5 & 31 \\
\hline & & & $1-25 k$ & 8 & 23 \\
\hline & & & $25 k-50 k$ & 2 & 18 \\
\hline \multirow[t]{2}{*}{1.10 (micro) } & 20 & 68 & $50 \mathrm{k}-100 \mathrm{k}$ & 1 & 17 \\
\hline & & & $100 \mathrm{k}-250 \mathrm{k}$ & 5 & 16 \\
\hline \multirow[t]{2}{*}{11.50 (smail) } & 3 & 10 & $250 \mathrm{k} \cdot 500 \mathrm{k}$ & 2 & 12 \\
\hline & & & $500 k-1 m$ & 2 & 9 \\
\hline $50-250$ & 0 & 3 & $1 m-10 m$ & 5 & 12 \\
\hline \multicolumn{6}{|l|}{ (medium) } \\
\hline $250+$ (large) & 0 & 0 & $10 \mathrm{mt}$ & 0 & 2 \\
\hline $\begin{array}{l}\text { Total } \\
\text { employment }\end{array}$ & 126 & 683 & $\begin{array}{l}\text { Total turnover } \\
\text { (kf) }\end{array}$ & 17016 & 80596 \\
\hline $\begin{array}{l}\text { Mean } \\
\text { employment }\end{array}$ & 4.2 & 4.9 & $\begin{array}{l}\text { Mean turnover } \\
\text { (kf) }\end{array}$ & 583 & 633 \\
\hline
\end{tabular}

Taken together the Chalmers spin-offs employ approximately 800 persons, and have a turnover of 97.6 million pounds. On the average each firm had 4.8 employees and a turnover of $£ 623 \mathrm{k}$, figures considerably lower than for the Oxford spinoffs. Also, the ratio between generated spin-off employment and academic and research staff is lower in the Chalmers case $(809 / 1600=0,506)$. However, if the Oxford outlier is excluded (a ratio of $(3959-1834) / 4600=0,27)$ the Chalmers ratio is in fact higher.

T-tests of different measures of spin-off size and growth are presented in Table 5. Here it is confirmed that the Oxford spin-offs are significantly larger and have demonstrated higher growth than the Chalmers spin-offs. Moreover, if the Oxford outlier is excluded from the analysis all measures of differences in size and growth are statistically significant at $\mathrm{p}<0,05$. 
Table 5. Spin-off performance.

\begin{tabular}{|c|c|c|c|c|c|c|}
\hline & $\begin{array}{l}\text { axford } \\
\text { chaimers }\end{array}$ & N & Mean & Sld Deviation & $\begin{array}{l}\text { Levene's test } \\
\text { for equality of } \\
\text { variances }\end{array}$ & $\begin{array}{c}\text { H-lest } \\
\text { Sig (2-tailed) }\end{array}$ \\
\hline \multirow[t]{2}{*}{ growthturnover } & $a x$ & 71 & 332091 & 1282820 & \multirow[t]{2}{*}{000} & \multirow[t]{2}{*}{.083} \\
\hline & eh & 192 & 43907 & 105045 & & \\
\hline \multirow[t]{2}{*}{ turnover } & $\alpha x$ & 71 & 6065120 & 40080008 & \multirow[t]{2}{*}{.001} & \multirow[t]{2}{*}{.247} \\
\hline & ch & 193 & 515740 & 1681002 & & \\
\hline \multirow[t]{2}{*}{ intarnover } & $0 x$ & 71 & 10,03 & 5,73 & \multirow[t]{2}{*}{540} & \multirow[t]{2}{*}{.011} \\
\hline & $\mathrm{ch}$ & 193 & 9,01 & 5,60 & & \\
\hline \multirow[t]{2}{*}{ employees } & $\alpha x$ & 69 & 57,38 & 221,04 & \multirow[t]{2}{*}{, 000} & \multirow[t]{2}{*}{.052} \\
\hline & eth & 170 & 4,78 & 15,05 & & \\
\hline \multirow{2}{*}{$\begin{array}{l}\text { Ingrowenturnar } \\
\text { or }\end{array}$} & ox & 71 & 8,51 & 5,08 & \multirow[t]{2}{*}{.722} & \multirow[t]{2}{*}{.004} \\
\hline & ch & 191 & 6,60 & 4,67 & & \\
\hline
\end{tabular}

Also noteworthy (in Table 4) is that the spin-offs without patents outperform the 33 Chalmers spin-offs with patents. Moreover, checking figures of profitability among the Chalmers spin-offs show that the patent-based ones in fact generates a loss (on average a loss of $£ 100 \mathrm{k}$ in 2011 ) while the non-patent-based spin-offs instead are more profitable (on average $£ 27 \mathrm{k}$ in 2011). Thus, the majority of the Chalmers spin-offs are small non-patent-based firms with a small profitability.

Further we performed linear regressions of size and growth to better understand what can explain the performance of the spin-offs. Table 6 presents the results of the two regression models; Model 1 with the logarithmic value for turnover representing the Size of the firm, and Model 2 with the average annual growth in turnover representing Growth. Model 2 has been separated into Model 2a and 2b. Model $2 \mathrm{a}$ includes the growth of all firms, while Model $2 \mathrm{~b}$ excludes the one Oxford outlier with extreme high growth. 
Table 6. Spin-off performance, regression log turnover and average growth.

\begin{tabular}{|l|c|c|c|}
\hline & $\begin{array}{c}\text { Model 1 } \\
\text { Size }\end{array}$ & $\begin{array}{c}\text { Model 2a } \\
\text { Growth }\end{array}$ & $\begin{array}{c}\text { Model 2b } \\
\text { Growth, outlier } \\
\text { excluded }\end{array}$ \\
\hline constant &, $198^{* * *}$ &, 049 &,- 28 \\
age &, 080 &, $557^{* * *}$ &, 020 \\
patents &, $215^{* *}$ &, $118^{* *}$ &, $282^{* * *}$ \\
Oxford/Chalmers &,$- 123+$ &,$- 201^{* * *}$ &,$- 222^{* *}$ \\
biopharma &, $120+$ &, $129^{*}$ &, $129^{*}$ \\
engineering &, 091 &,- 003 &,- 005 \\
consultancy & .116 & .388 & .117 \\
\hline R2 & .095 & .374 & .096 \\
Adj R2 & $5,627^{* * *}$ & $27,102^{* * *}$ & $5,606^{* * *}$ \\
\hline F(F-sign) & & & \\
\hline
\end{tabular}

Significance level: $*<.05$, and $* *<.01 ., * * * .001$ and $+<.10$

The regressions confirm that Oxford spin-offs outperform Chalmers spin-offs, and that this is the case even if the Oxford outlier is excluded from the analysis. Quite naturally, the age of the spin-off is important for the size, but not for the average growth of the firm. Also being in engineering has a positive effect on size and growth, while spin-offs in biopharma instead enjoy a limited growth and smaller size. Taken together this suggests that especially Oxford spin-offs in engineering are likely to be high-performing firms. In addition, Table 6 also tells that a high number of patents have positive effect on average growth, but it should be noted that this effect disappears when the Oxford outlier is excluded. This firm not only holds a lot of patents, it is also demonstrating a considerable growth.

\section{University affiliation of academic directors}

Academics, who are involved in Oxford spin-off activities, are from 40 (out of 70) Oxford departments and Colleges. More than half of the departments and Colleges in the sample only produced 1-2 spin-off companies. However, 16 spin-off companies are created from the Department of Engineering Science, followed by 7 companies spun out from the Physical and Theoretical Chemistry Laboratory, and 6 companies from Department of Chemistry, Department of Biochemistry and Magdalen College respectively.

The consolidated picture of data for Oxford (e.g., number of patents, number of academics, number of patents filed within the University IP system, and number of patents with potential academic bypass) shows that academics from the department of Engineering Science owned a high number of patents, in which the number of patents disclosed within the University IP system is slightly more than the 
number of patents filed outside the formal IP system. Conversely, a different pattern has been observed for academics from the department of Biochemistry. They are more prone to filing patents outside the IP system. This can possibly be explained by the potentially higher commercial value of the patents.

In the Chalmers case the university does not own the IP, and thus, bypassing is not possible. Instead Figure 8 is used to illustrate the frequencies of both spin-offs and patenting from the 17 Chalmers departments.

Fig. 8: Number of Patents and spin-offs by Chalmers Departments.

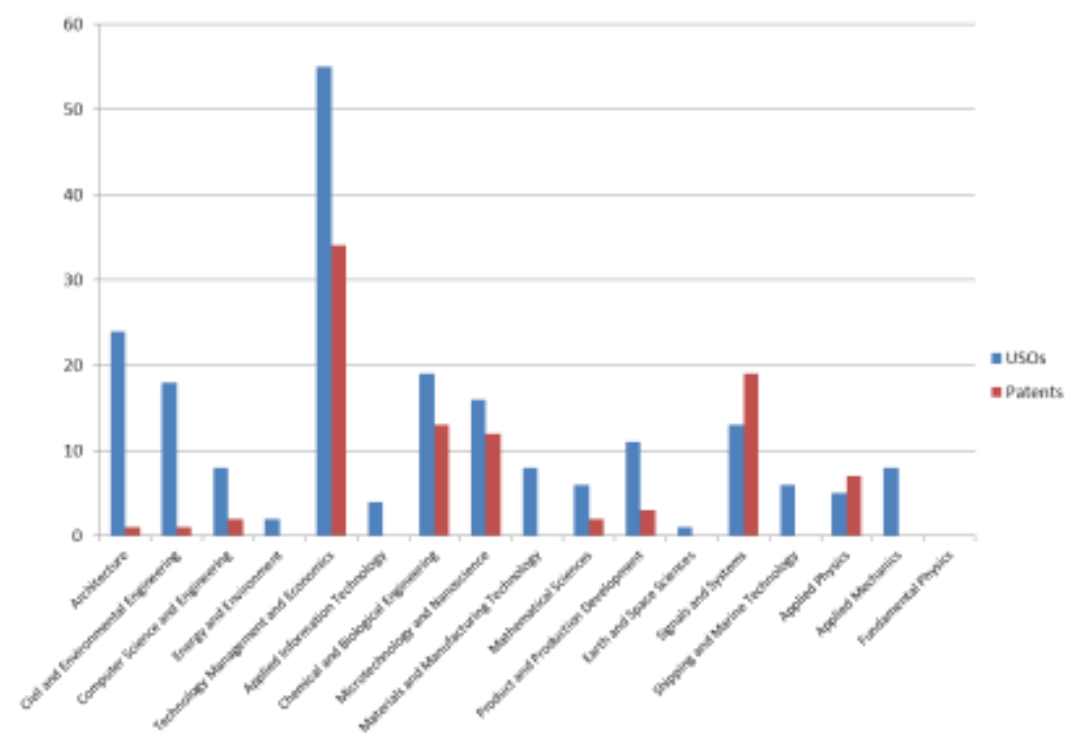

As can be seen in the figure the highest number of spin-offs and patents has originated from the department of Technology Management and Economics. At first this might seem odd, but is easily explained by the fact that researchers at this department are active in the Chalmers School of Entrepreneurship with its unique venture creation model. In addition, the departments of Chemical and Biological Engineering, Microtechnology and Nanoscience, and Signals and Systems, also generate a relatively high share of spin-offs and patents. The departments of Architecture and Civil and Environmental Engineering also generate many spin-offs, even though these in general do not hold any patents. 


\section{Discussion and Conclusions}

In this chapter we asked how different institutional settings affect the commercialization and exploitation of university research in Europe? By comparing two universities with well-established commercialization systems, we found that institutional settings matter in the rate and type of entrepreneurial activities (spin-off companies and patents). In relation to its size, the spin-off creation at Chalmers University is on par with other Swedish universities. Instead, Oxford University is an outlier among UK universities, only Cambridge University has created more spin-offs. Despite of this, our empirical data show that Chalmers University, with an inventor ownership model, generates a higher number of spin-off firms. At the University of Oxford, with a university ownership model, the frequency of university spin-offs was found to be lower, but instead the firms performed better.

Our findings are consistent with previous studies, which show that a significant percentage of academics do not engage in the entrepreneurial activities through formal IP channels. The idea of an entrepreneurial university rests on the idea that universities can and may act entrepreneurial themselves, for example by exploiting and commercializing academic research. This is often done through the formation of technology transfer offices with a specific task to commercialize university IP, both through licensing knowledge and set up of university spin-offs. In this way, entrepreneurial universities are often assumed to contribute and encourage university entrepreneurship. In other institutional settings where universities themselves do not own the research results and IP, one of the basic conditions for an entrepreneurial university simply does not exist. Even so, as demonstrated in this chapter, this does not hinder university entrepreneurship. In fact, as found in the Chalmers case, university entrepreneurship can be very frequent even in cases where the rights to commercialize research results rest with the academic researcher.

Thus, the most important finding in this chapter is that universities can contribute to entrepreneurship and act entrepreneurial even when the IP rests with the university inventor, a function of decisions made within the prevailing system of government. Moreover, a considerable amount of university entrepreneurship does take place outside the formal IP system. This is not necessarily a problem that universities should try to stop - to encourage university entrepreneurship an entrepreneurial university could also try to encourage the kind of entrepreneurship that is not necessarily based on university IP.

Furthermore, our results indicate that even though there is a high frequency of university spin-offs in the Chalmers case, these are small and usually not based on patents. Compared to the Oxford case, the Chalmers spin-offs are considerably smaller, often acting as consultants. Interesting, the patent-based Chalmers spin- 
offs are not performing as well as the non-patent-based ones; they are both smaller and less profitable. Having spin-offs acting as consultants can of course be important when the spin-offs functions as research boutiques and transfer research results to other companies and organizations which use the IP to create growth and renewal. To further analyze such effects of technology transfer from university spin-offs is an important task for future research.

One limitation in this study is that due to the lack of data on period(s) of employment with the University of Oxford, this study cannot conclude authoritatively on the academic bypassing of Isis Innovation/University of Oxford for the disclosure or exploitation of their inventions. Even though the case provided in this study is drawn from a single institution and the data is rather descriptive, our findings appear to be consistent with previous studies, which showed that a significant percentage of academics do not engage in the entrepreneurial activities through formal IP channels. In line with this further research on university spin-off bypassing should be encouraged for a better understanding of European university entrepreneurship outside of the formal IP system. The research on university spin-offs outside the IP system has been undertaken extensively in the U.S., while there, to the best of our knowledge, are yet no such studies carried out in European context.

Our findings thus have some suggestions to the modus operandi of academic entrepreneurship. An attempt from policy makers or university administrators to highlight the importance of intellectual property rights towards academic entrepreneurships seems to be focusing only on a fraction of academic entrepreneurial activities, whereas omitting some vital portions of them. In addition, the existing Oxford system that the entrepreneurial activities are expedited through Technology Transfer Office falls short in supporting a substantial segment of academic entrepreneurial activities, which take place outside of the formal university IP system. Otherwise, the aim and attempt of universities to employ academic entrepreneurship for the creation and contribution to regional economic development might be undermined versus its prospect.

\section{Acknowledgments}

We would like to thank Hallur Sigurdarsson, CBS, Denmark and Sten Dieden, CIRCLE, Lund University, for assistance with the Chalmers data. 


\section{References}

Agrawal, A. (2001) 'University-to-industry knowledge transfer: literature review and unanswered questions' International Journal of Management Reviews, Vol.3, pp. 285-302.

Allen, T. (1995), Managing the Flow of Technology Transfer and the Dissemination of Technological Information within the R\&D Organization, 2nd ed., MIT Press, MA.

Arundel, A., Bordoy, C., (2008) 'Developing internationally comparable indicators for the commercialization of publicly-funded research', Working paper series \#2008-075, UNU-MERIT, Maastricht, The Netherlands.

Åstebro, T., Bazzazian, N., Braguinsky, S., (2012). Startups by recent university graduates and their faculty: Implications for university entrepreneurship policy, Research Policy, 41, 663 677.

Bergman, E.M., (2010) 'Marshall's Dilemma and Commercialization of European Research', paper presented at the 2010 ERSA (The European Regional Science Association) Congress, Jönköping, August 19-23.

Bonaccorsi, A. and Piccaluga, A. (1994) 'A Theoretical Framework for the Evaluation of University-Industry Relationships, R\&D Management, 24,3 229-247.

Breznitz, S. (2011) 'Improving or Impairing? Following Technology Transfer Changes at the University of Cambridge', Regional Studies, 45, 463-478

BIS (Department of Business Innovation and Skills), (2009), Annual Innovation Report 2008/09, London, UK.

Carraz, R., (2008) 'Incentives to patent in a leading Japanese university. Paper presented at the SPF Project on Role of Universities in National Innovation Systems', 3rd Workshop, Beijing (30-31 October 2008).

Cohen, W.M., Nelson, R.R. and Walsh, J.P. (2002) 'Links and Impacts: the Influence of Public Research on Industrial R\&D', Management Science, 48, 1,1-23.

D'Este, P. and Patel, P. (2007) 'University-industry linkages in the UK: what are the factors underlying the variety of interactions with industry?' Research Policy,.36, 1295-1313.

Di Gregorio, D., Shane, S., (2003) 'Why so some universities generate more start-ups than others?' Research Policy, 32.209-227.

Ejermo O., (2012) 'Gammal uppfinner bäst - lärosätenas effekter på patentering via anställda och studenter' Ekonomisk Debatt (2), 37-51.

Ejermo, O., (2011) Svenska uppfinnare - nytt datamaterial och ny inblick i innovationsprocessen, Working Paper 2011:14, Tillväxtanalys, Östersund.

Etzkowitz, H (1983) 'Entrepreneurial Scientists and Entrepreneurial Universities in American Academic Science' Minerva 21, 198-233.

Etzkowitz, H., and Klofsten, M. (2005). The innovating region: toward a theory of knowledge-based regional development. R\&D Management, 35(3), 243-255.

European Commission, (1993) Growth, Competitiveness, Employment: The Challenges and Ways Forward into the 21st Century - White Paper COM (93) 700, December

European Commission, (1995) Green Paper on Innovation, COM (95) 688 final, 20 December.

European Commission, (2007) Improving knowledge transfer between research institutions and industry across Europe, DG Research and DG Enterprise and Industry, EUR 22836, Brussels.

EU,(2008) Professor's privilege: Monitoring and Analysis of technology transfer and intellectua property regimes and their use, draft report to the Commission (DG Research), Dec 2008.

Faulkner, W. (1994) 'Conceptualizing Knowledge Used in Innovation: a Second Look at the Science-Technology Distinction and Industrial Innovation' Science, Technology, and Human Values, 19, 4,425-458.

Fini, R., Lacetera, N., and Shane, S. (2010) 'Inside or Outside the IP System? Business Creation in Academic' Research Policy 39, 1060-1069.

Geuna, A., Rossi, F.( 2011) 'Changes to university IPR regulations in Europe and the impact on academic patenting' Research Policy 30, 1068-1076. 
Harrison, R and Leitch, C (2010) Spin-off companies, the Entrepreneurial System and Regional Development in the UK Regional Studies 44, 9 1241-1262

Henderson, R., Jaffe, A.B., Trajtenberg, M., (1998) 'Universities as a Source of Commercial Technology: a Detailed Analysis of University Patenting, 1965-1988' Review of Economics and Statistics, 80119-127.

Isis Innovation, (2013), About Isis, retrieve from: http://www.isis-innovation.com/about/, accessed 25 April 2013.

Jacobsson, S., Lindholm Dahlstrand, Å., and Elg, L. (2013) 'Is the commercialization of European academic R\&D weak? - a critical assessment of a dominant belief and associated policy responses', Research Policy, 42, 874-885.

Jensen, R., Thursby, M., (2001) 'Proofs and Prototypes for Sale: The Licensing of University Inventions' American Economic Review,91 240-259.

Jensen, R.A., Thursby, J., Thursby, M., (2003), 'Disclosure and Licensing of University Inventions: "the Best We Can Do With the S**t We Get to Work With? 'International Journal of Industrial Organization, 21,1271-1300.

Kenney, M., Patton, D. (2009) 'Reconsidering the Bayh-Dole Act and the Current University Invention Ownership Model', Research Policy, 38, 1407-1422.

Kenny, M., Patton, D. 2011. Does inventor ownership encourage university research-derived entrepreneurship? A six university comparison, Research Policy, 40, 1100-1112.

Lawton Smith, H. and Ho, K. (2006) 'Measuring the Performance of Oxford University, Oxford Brookes University and the Government Laboratories' Spin-off Companies' Research Policy, 35 1554-1568.

Lissoni, F., Llerena, P., McKelvey, M., Sanditov, B. (2009) 'Academic patenting in Europe; evidence on France, Italy and Sweden from the KEINS database', in McKelvey, M., Holmén, M. (Eds), Learning to compete in European universities. From social institution to knowledge business, Edgar Elgar, Cheltenham, U.K.

Mansfield, E., (1995) 'Academic Research Underlying Industrial Innovations: Sources, Characteristics, and Financing' The Review of Economics and Statistics, 77, 55-65.

Mansfield, E., (1998). 'Academic research and industrial innovation: An update of empirical findings' Research Policy, 26, 773-776.

Markman, G., Gianiodis, P., Phan, P., Balkin, D., (2004), Entrepreneurship from the Ivory Tower: Do Incentive Systems Matter? Journal of Technology Transfer, 29,353-364.

Markman, G.D., Gianiodis, P.T., Phan, P.H., (2008) 'Full-Time Faculty or Part-Time Entrepreneurs, IEEE Transactions on Engineering Management, 55, 1, 29-36.

Meyer-Krahmer, F. and Schmoch, U. (1998). Science-based Technologies: University-Industry Interactions in Four Fields, Research Policy, .27835-851.

Mowery, D., Sampat, B., Ziedonis, A., (2002) 'Learning to Patent: Institutional Experience, Learning, and the Characteristics of U.S. University Patents after the Bayh-Dole act, 19811992' Management Science, 48, 73-89.

Mowery, D., Ziedonis, A., (2002), 'Academic Patent Quality and Quantity Before and After the Bayh-Dole Act in the United States', Research Policy, 31,399-418.

Mustar, P., Renault, M., Colombo, M., Piva, E., Fontes, M., Lockett, A., Wright, M., Clarysse, B., Moray, N., (2006), Conceptualising the Heterogeneity of Research based Spin-offs: A Multi-Dimensional Taxonomy, Research Policy, 35,289-308.

Nerkar, A., Shane, S., (2003) 'When Do Start-ups that Exploit Patented Academic Knowledge Survive?' International Journal of Industrial Organization, 21, 1391-1410.

O'Shea, R., Allen, T., O'Gorman, C., Roche, F. (2004), Universities and Technology Transfer: A Review of Academic Entrepreneurship Literature, Irish Journal of Management, 25, 2,11-29.

QS Top Universities, (2012), QS World University Rankings by Subject 2012 - Medical, retrieve from: http://www.topuniversities.com/university-rankings/university-subjectrankings/2012/medicine, accessed 25 April 2013. 
QS Top Universities, (2012), QS World University Rankings by Subject 2012 - Biological Science, retrieve from: http://www.topuniversities.com/university-rankings/university-subjectrankings/2012/biological-sciences, accessed 25 April 2013.

Roberts, E., (1991), Entrepreneurs in high technology, Lessons from MIT and Beyond, Oxford University Press: New York.

Sampat, B.N., Mowery, D.C., Ziedonis, A.A., (2003) 'Changes in University Patent Quality after the Bayh-Dole Act: a Re-Examination' International Journal of Industrial Organization, 21 1371-1390.

Saxenian, A. (1994), Regional Advantage: Culture and Competition in Silicon Valley and Route 128, Harvard University Press: Cambridge, MA.

Shane, S., (2004) Academic Entrepreneurship : university spinoffs and wealth creation, Northampton:MA, Edward Elgar.

Takahashi, M., Carraz, R., (2011) 'Academic patenting in Japan: illustration from a leading Japanese university', in Wong, P.K. (Ed.) Academic Entrepreneurship in Asia, Cheltenham: Edward Elgar Publishing, 86-107.

Thursby, J.G., Thursby, M.C., (2005) 'Gender Patterns of Research and Licensing Activity of Science and Engineering Faculty', Journal of Technology Transfer, 30,343-353.

Times Higher Education World University Ranking, (2012), World University Rankings 2012/13, retrieve from: http://www.timeshighereducation.co.uk/world-universityrankings/2012-13/world-ranking, accessed 25 April 2013.

Valentin, F., Jensen, R.L., (2007) 'Effects on academia-industry collaboration of extending university property rights, Journal of Technology Transfer, 32,3, 251-276. 